\title{
Improving Chilling Tolerance of Maize Seedlings under Cold Conditions by Spermine Application
}

\author{
Amir Hossein SAEIDNEJAD ${ }^{1 *}$, Farzin POURAMIR ${ }^{1}$, Mahdi NAGHIZADEH ${ }^{2}$ \\ ${ }^{1}$ Ferdowsi University of Mashhad, Department of Agronomy, Azadi sq, 91775-1163 Mashhad, Iran; am_sa10@stu.um.ac.ir (*corresponding author) \\ ${ }^{2}$ Shahid Bahonar University of Kerman, Department of Agronomy and Plant Breeding, Kerman, Iran
}

\begin{abstract}
Low temperature is an important abiotic stress which reduces crops growth and productivity and causes physiological damages to cellular structures. The aim of this study was to investigate the probability of spermine application to improve chilling tolerance of maize under stress conditions. The treatments were included seed priming with spermine (30,60 and $90 \mathrm{mg} / \mathrm{l}$ solutions) and normal and stress condition. Seed emergence was improved by spermine priming on both conditions and mean emergence time (MET) was also decreased with priming. Shoot and root length was highly reduced under stress conditions, but the treated seeds were improved along with increased spermine concentration. Seedling dry weight was also affected by priming and reduced weight of stressful seedlings was alleviated by spermine priming. Decreased relative water content on seedlings under stress was elevated by the treatments and significantly increased. Electrolyte leakage was also recovered by applied treatments while it was adversely decreased on cold conditions. Antioxidative system was highly responded to spermine application. Superoxide dismutase (SOD) activity increased on both normal and stress conditions, but a little decrease was observed on seedlings treated with 90 ppm level and under chilling conditions. Catalase activity was also amplified by spermine treatments. Priming had a great effect on ascorbate peroxidase (APX) activity on both stressful and normal seedlings and increased it compare with non treated seedlings. It is also important to note that with increasing spermine concentration to $90 \mathrm{ppm}$, no considerable differences were observed. Thus, $60 \mathrm{ppm}$ concentration could be proposed as the appropriate level of spermine in order to improve chilling tolerance of maize seedlings.
\end{abstract}

Keywords: antioxidants activity, maize, polyamine, seed, stress

\section{Introduction}

Low temperature is known as an important limiting factor which reduces plants productivity around the world. Maize (Zea mays L.) is a thermophilic crop and optimum temperature for maize germination is between $25-28^{\circ} \mathrm{C}$. Low temperature causes injuries to maize germination and seedling growth, so it will be damaging specially for early spring planting (Parera and Cantliffe, 1994).

Chilling stress could induce different kinds of damages such as reducing growth rate (Sowinski et al., 2005; Verheul et al., 1996) water uptake disturbance (Aroca et al., 2003a) photosynthesis efficiency (Foyer et al., 2002; Haldimann, 1997) changes in membrane properties (Pinhero et al., 1997) and particularly considerable increase in reactive oxygen species (ROS) production (Foyer et al., 2002) as well as enzymatic and non-enzymatic antioxidants (Leipner et al., 1999; Skrudlik et al., 2000).

A common consequence of most environmental stresses (Hayat et al., 2007; Muthuchelian et al., 2001; Sairam et al., 2005) is an increased production of ROS. Chilling has also similar effects which was studied by some researches (Farooq et al., 2008a; 2008b). These ROS, such as superoxide radical $\left(\mathrm{O}^{-}\right)$, hydrogen peroxide $\left(\mathrm{H}_{2} \mathrm{O}_{2}\right)$ and hydroxyl $\left(\mathrm{HO}^{-}\right)$are exceedingly toxic to cellular and subcellular structures (Schutzendubel and Polle, 2002). How- ever, plants have an efficient antioxidant system includes enzymatic and non-enzymatic antioxidants (superoxide dismutase, peroxidase, catalase, and glutathione reductase, carotenoids, glutathione, ascorbic acid) and also some important metabolites like proline to counter with oxidative stress and protect the plants from oxidative damage (Apel and Hirt, 2004).

Polyamines (PAs) are ubiquitous low-molecularweight amines involved in of plant growth and development regulation (Martin-Tanguy, 2001). Polyatomic nature of this compounds made them able to interact with proteins, nucleic acids and membrane phospholipids and this leads to activating or stabilizing these molecules. The diamine putrescine (Put), the triamine spermidine (Spd) and the tetraamine spermine ( $\mathrm{Spm}$ ) are the most common polyamines which may be present in the free, soluble conjugated and insoluble bound forms.

There have been several mechanisms proposed for the protective effects of PAs as well as stabilizing DNA structure (Kasinathan and Wingler, 2004) impeding lipid peroxidation and membrane integrity (Ha et al., 1998). Kubis (2008) also indicated that PAs may acts as free radicals scavengers. In fact, PAs accumulation could protect plant cells when they exposed to environmental stresses (Nayyar and Chander, 2004; Sanchez et al., 2005). 
Roy et al. (2005) and Kubis (2008) showed that exogenous application Spd could prevent the electrolyte and amino acid leakage or recovering the plasma membrane damage in rice cultivars in response to salinity, in chilling tolerance and in protection of water stressed cucumber leaves. The protective role of $\mathrm{Spm}$ against salt stress has been well established in Arabidopsis (Yamaguchi et al., 2006).

Several studies reported priming advantages on germination and stand establishment improving (Basra et al., 2005; Farooq et al., 2006a; 2006b; 2006c). Priming provides faster and synchronous seedling emergence (McDonald, 1999). Moreover, priming has also been found effective to increase the germination under chilling conditions. Farooq et al. (2008a) proposed seed priming as a tool to improve chilling tolerance in late-sown wheat.

In the present study, the effects of seed priming with different concentrations of spermine solutions on maize plants under normal and chilling conditions were investigated to explore the possible biochemical basis of chilling tolerance.

\section{Materials and methods}

Plant materials and growth conditions

Seeds of Maize (Single cross 704) were obtained from the Center of Agricultural Researches and Natural Resources, Khorasan Razavi, Iran. Seeds were surface sterilized with $2 \% \mathrm{HgCl}_{2}$ for $20 \mathrm{~min}$, washed twice with distilled water and air dried. For seed treatments, seeds were soaked in 30,60 and $90 \mathrm{ppm}$ solutions of spermine (solved in distilled water) for 24 hours. Untreated seeds (treated by water) were considered as control.

Treated and untreated seeds were sown in 1 liter plastic pots containing water-washed sand, and then placed in a growth chamber with a photosynthetically active photon flux density of $320 \mathrm{mmol} \mathrm{m}^{-2} \mathrm{~s}^{-1}$ and a photoperiod of $16 / 8 \mathrm{~h} \mathrm{light} /$ dark. One series of pots was placed at optimal temperature $\left(27^{\circ} \mathrm{C}\right)$ as control, while the other was kept at chilling stress $\left(15^{\circ} \mathrm{C}\right)$ during the period of study. The number of emerged seedlings was daily recorded. Time required to reach $50 \%$ emergence of seedlings (E50) was calculated by following formulae of Coolbear et al. (1984) modified by Farooq et al. (2005):

$$
\mathrm{E} 50=t_{i}+\frac{\left.[(N / 2)]-n_{i}\right]\left(t_{j}-t_{i}\right)}{n_{j}-n_{i}}
$$

Where $N$ is the final number of emerged seeds, and $n_{i}$ and $n_{j}$ are the cumulative number of seeds emerged counts at times $t_{i}$ and $t_{j}$ when $n_{i}<N / 2<n_{j}$.

Mean emergence time (MET) was calculated according to the equation of Ellis and Roberts (1981):
$\operatorname{MET}=\frac{\sum D_{n}}{\sum n}$

Where $n$ is the number of seeds which emerged on day $D$, and $D$ is the number of days counted from the beginning of emergence.

After 24 days of emergence, samples were collected for biochemical analysis. Seedlings were carefully removed to evaluate seedling shoot and root length. Seedling fresh weight was determined immediately after harvest while dry weight was taken after drying at $70^{\circ} \mathrm{C}$ for 2 days.

\section{Membrane permeability}

Membrane permeability was determined by measuring the electrolyte leakage using the method of Blum and Ebercon (1981). Six leaf samples were washed with distilled water and soaked in $6 \mathrm{~mL}$ of distilled water for $12 \mathrm{~h}$. The conductivity of the solution (C1) was measured with a conductivity meter. Samples were then heated in boiling water for $20 \mathrm{~min}$ and then cooled to room temperature. The conductivity of killed tissues (C2) was again measured. Membrane permeability was calculated as the ratio between $\mathrm{C} 1$ and $\mathrm{C} 2$.

\section{Relative water content}

In order to determine relative water content (RWC) fresh leaf discs with $2 \mathrm{~cm}^{2}$ diameter were weighted floated on deionized water for saturation until 24 hours and saturated leaf weight was recorded. Dry mass was also noted after dehydration at $70^{\circ} \mathrm{C}$ for $48 \mathrm{~h}$. the following formula was used to calculate RWC (Hayat et al., 2007):

$$
\mathrm{RWC}=\frac{\text { Fresh weight }- \text { dry weight }}{\text { Turgor weight }- \text { dryweight }}
$$

\section{Extraction and determination of enzyme activities}

Leaves tissue $(100 \mathrm{mg} \mathrm{FW})$ were placed into liquid nitrogen and then homogenized with a pre-chilled mortar and pestle under ice cold-conditions in $4 \mathrm{~mL} 50 \mathrm{mM}$ potassium phosphate buffer, $\mathrm{pH} 7.0$, with adding $1 \mathrm{mM}$ EDTA. The homogenate was centrifuged at $15000 \mathrm{rpm}$, at $4^{\circ} \mathrm{C}$ for $20 \mathrm{~min}$. The supernatant was stored at $-20^{\circ} \mathrm{C}$ and used for determination of enzyme activity.

Superoxide dismutase (SOD, EC 1.15.1.1) activity was assessed by the method of Giannopolitis and Ries (1977). The inhibition of photochemical reduction of NBT was measured and the color was developed by adding $2.4 \mathrm{~mL}$ of $50 \mathrm{mM}$ potassium phosphate buffer solution $(\mathrm{pH} 7.8)$, $0.2 \mathrm{~mL}$ of $195 \mathrm{mM}$ methionine, $0.1 \mathrm{~mL}$ of $0.3 \mathrm{mM}$ EDTA, $0.2 \mathrm{~mL}$ of $1.125 \mathrm{mM} \mathrm{NBT}$ and $0.2 \mathrm{~mL}$ of $60 \mu \mathrm{M}$ riboflavin to $50 \mu \mathrm{L}$ enzyme extract. Reaction mixtures were illuminated for about $15 \mathrm{~min}$ at 5000 Lux light intensity. The solution absorbance was measured at $560 \mathrm{~nm}$. One unit of SOD was defined as the amount of enzyme causing halfmaximal inhibition of the NBT reduction. 
112

Ascorbate peroxidase (APX, EC 1.11.1.11) activity was measured based on the method of Nakano and Asada, 1981. The reactive solution contained $50 \mathrm{mM}$ sodium phosphate buffer ( $\mathrm{pH} 7.0$ ), $0.5 \mathrm{mM}$ ascorbate, $0.1 \mathrm{mM}$ $\mathrm{H}_{2} \mathrm{O}_{2}$ and $10 \mu \mathrm{l}$ of enzyme extracts. The decrease in absorbance at $290 \mathrm{~nm}$ was recorded. Extinction coefficient of $2.8 \mathrm{mM}^{-1} \mathrm{~cm}^{-1}$ was used to calculate enzyme activity. One unit of APX was defined as the amount of degrading $1 \mu \mathrm{mol}$ of ascorbate $\mathrm{min}^{-1} \mathrm{mg}$ protein ${ }^{-1}$ under the assay conditions.

Catalase (CAT, EC 1.11.1.6) activity was determined following the utilization of $\mathrm{H}_{2} \mathrm{O}_{2}$ at $240 \mathrm{~nm}$ for $1 \mathrm{~min}$ (Aebi, 1984). The reaction mixture contained $100 \mathrm{mM}$ potassium phosphate buffer ( $\mathrm{pH} 7.0), 15 \mathrm{mM} \mathrm{H}_{2} \mathrm{O}_{2}$ and $50 \mu \mathrm{l}$ of enzyme extract in final volume of $3 \mathrm{ml}$. The enzyme activity was calculated using the extinction coefficient $\left(39.4 \mathrm{mM}^{-1} \mathrm{~cm}^{-1}\right)$ and expressed as units $(1 \mu \mathrm{mol}$ of $\mathrm{H}_{2} \mathrm{O}_{2}$ decomposed per minute) per mg protein.

\section{Statistical analysis}

The experiment was a $2 \times 4$ factorial based on a randomized complete block design with four replications and three seedlings on each pot. Analysis of variance performed using SAS 9.1 and general linear models (PROC GLM) procedure (SAS Institute, Cary, NC). The LSD test was used to comparison of means at $p=0.05$.

\section{Results and discussion}

\section{Growth parameters}

Exogenous application of spermine improved seed emergence under both optimal and stress conditions (Fig. 1A). Application of $30 \mathrm{ppm}$ spermine seed priming significantly decreased the E50, but it was increased with increasing spermine concentration. There were no signifi-

A

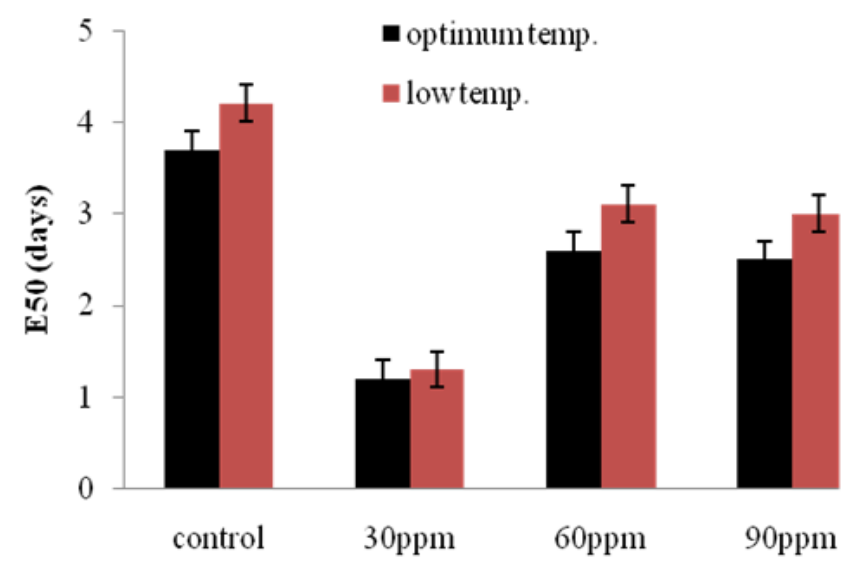

Pre-sowing spermine seed treatments cant differences between the 60 and $90 \mathrm{ppm}$ treatments, but still had the lower E50 compared with control treatment. (Xiong et al., 2002).

Chilling impairments mainly consist of alteration of metabolic processes, decrease in enzymatic activities, reduction of photosynthetic capacity and changes in membrane fluidity among others (Dubey, 1997). Plants adopt with the stressful conditions through different kind of mechanism, mostly by acclimation (Lee et al., 2002). There is a group of evidences which approved that cold acclimation could be achieved by exogenous application of PAs (Groppa and Benavides, 2008; Xiong et al., 2002). These compounds regulate plant growth and development through different physiological processes (Martin-Tanguy, 2001; Paschalidis and Roubelakis-Angelakis, 2005).

Mean emergence time (MET) was also significantly affected by priming such that along with increasing the spermine levels, MET was decreased (Fig.1B)., There was also no difference between the 60 and $90 \mathrm{ppm}$ treatment. The seedlings under chilling condition showed a noticeable decrease in shoot length, as well as root length, but it was improved on account of spermine treatments (Fig. $2 \mathrm{~A}$ and $\mathrm{B}$ ). There was a little decrease in both shoot and root length at $90 \mathrm{ppm}$ spermine concentration, which was not significant. It can be concluded that limiting effects of chilling on seedlings emergence and growth could be alleviated by spermine seed priming, but the suitable concentration is $60 \mathrm{ppm}$ and higher level will not be more efficient. Exogenous application of spermine as an important PAs improves germination properties and seedling length, which is related to the role of PAs on germination and primary growth regulation. Xu et al. (2010) were also observed the improving of germination percentage, index and mean germination time of chilling exposed Nicotiana tabacum primed with putrescine.

B

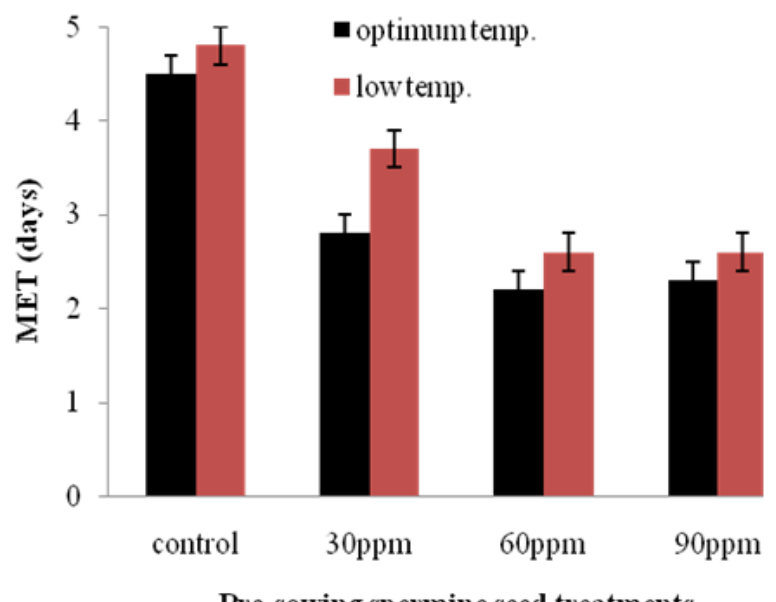

Pre-sowing spermine seed treatments

Fig. 1. Effect of spermine application on mean emergence time (MET) (A) and E50 (B) of maize seedlings under optimum and low temperature conditions. Data are the mean value of three replications \pm SE which represented by the vertical bar in each graph 


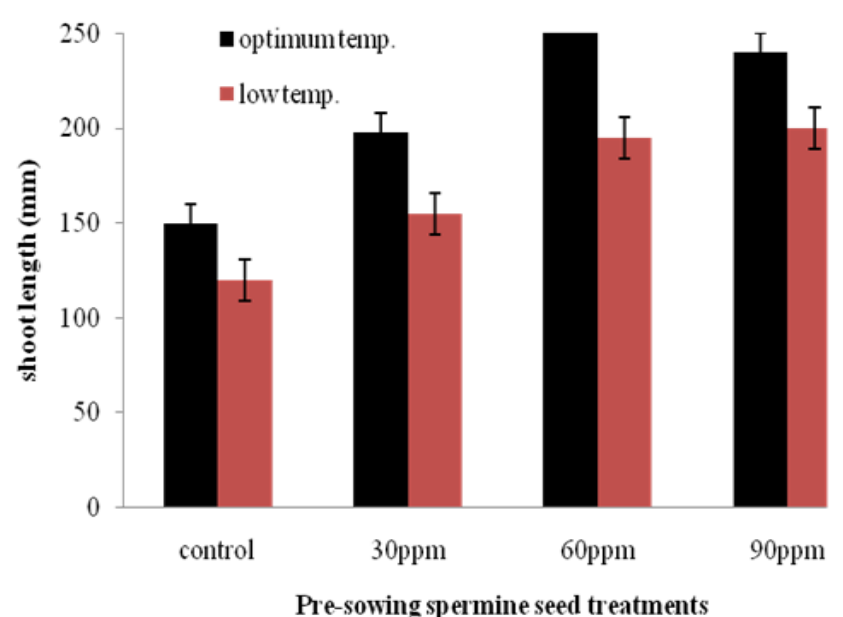

B

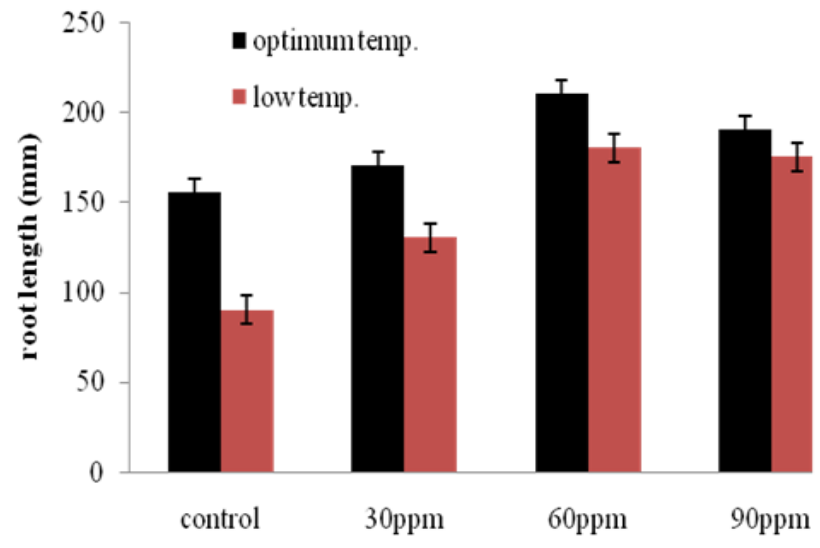

Pre-sowing spermine seed treatments

Fig. 2. Effect of spermine application on shoot (A) and root (B) length of maize seedlings under optimum and low temperature conditions. Data are the mean value of three replications $\pm S E$ which represented by the vertical bar in each graph

A

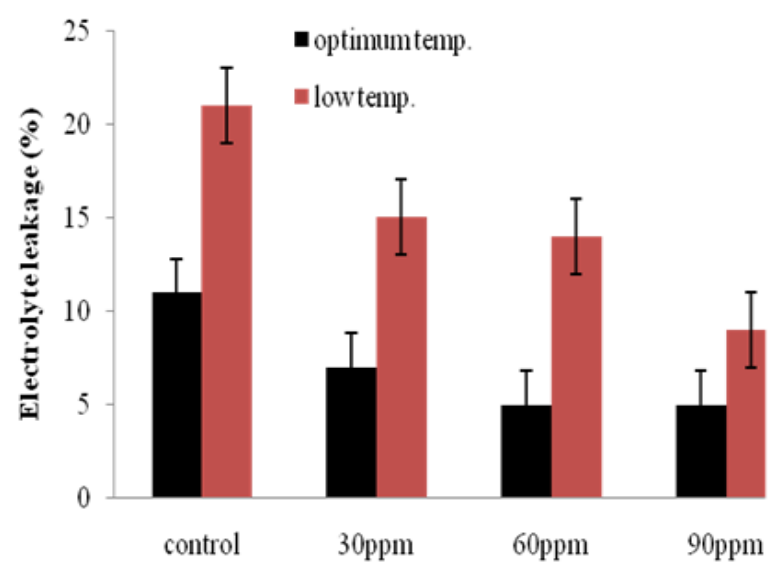

Pre-sowing spermine seed treatments
B

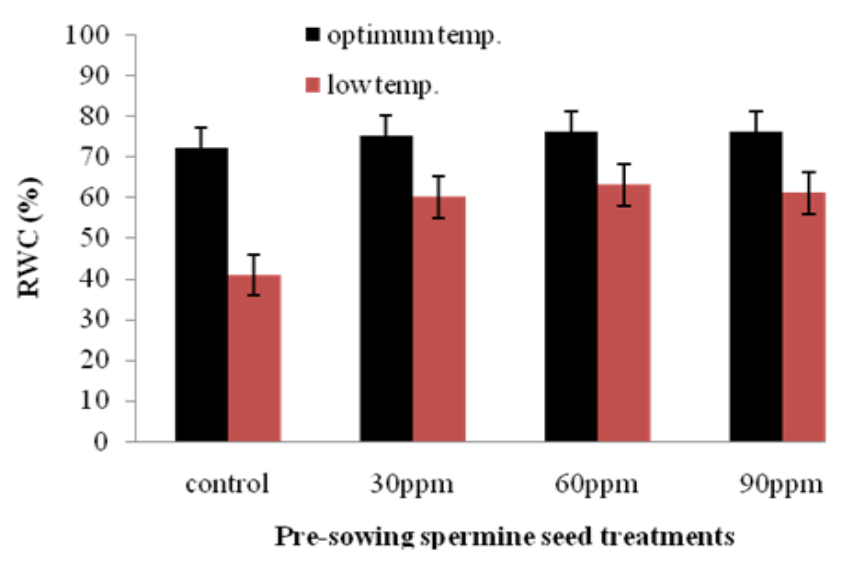

C

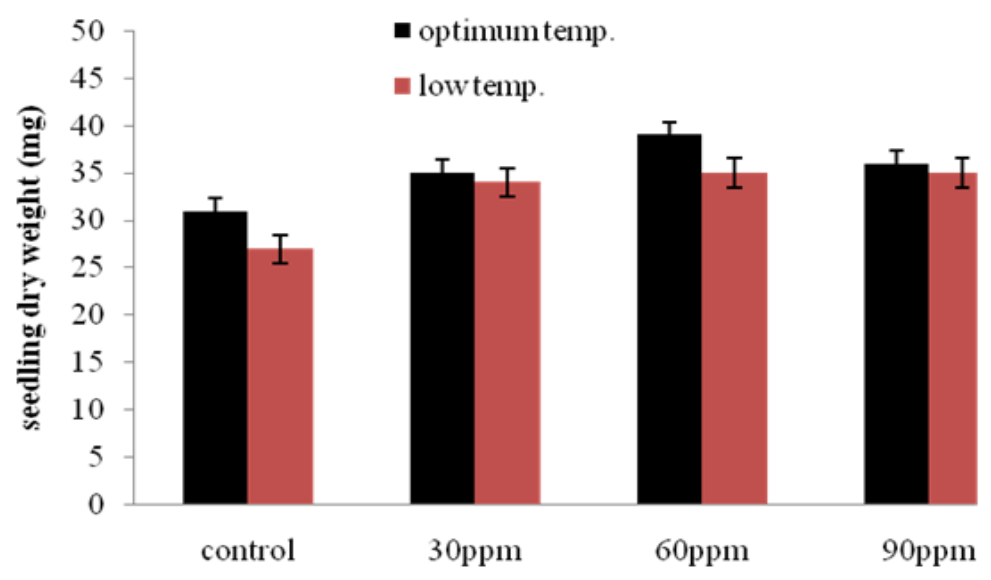

Pre-sowing spermine seed treatments

Fig. 3. Effect of spermine application on electrolyte leakage (A), relative water content (RWC) (B) and seedling dry weight (C) of maize seedlings under optimum and low temperature conditions. Data are the mean value of three replications \pm SE which represented by the vertical bar in each graph 
114

\section{Relative water content}

There was a drastic decrease on chilling exposed seedlings relative water content (RWC). But exogenous spermine application could enhance the RWC content and increased it, significantly (Fig. 3B). Plants grown under normal conditions showed a very slight increase on RWC. The considerable point here is that different spermine concentrations had no effect on RWC on both normal and stress conditions and RWC contents were nearly the same. So, the enhancement effect of spermine may be restricted to the low levels and increasing the applied concentration even may have negative side effects.

\section{Electrolyte leakage and seedling dry weight}

A decline on electrolyte leakage on both normal and stressful seedlings due to the spermine treatment was recorded during this experiment (Fig. 3A). Electrolyte leakage was adversely increased when the seedlings was exposed to chilling condition with no priming, but sper- mine treatment leads to reduce the electrolyte leakage and 90 ppm spermine concentration had the lowest amount. These effects on seedlings under none chilling conditions were less clear. Seedling dry weight was significantly affected by spermine treatments and it was increased on chilling stressed seedlings, as the others on control treatment (Fig. 3C). Like the previous, $90 \mathrm{ppm}$ spermine treatment was not efficient and seedling dry weight was a little decreased on optimum temperature, while it had no change on stressful seedlings.

Membranes are the major targets of environmental stresses (Leshem, 1992). Induced changes on plant cells under chilling stress are mainly related to an increase in membrane permeability, affecting membrane integrity and cell compartmentation under stress conditions (Campos et al., 2003). Enhanced electrolyte leakage was considered to be a symptom of stress-induced membrane damage and deterioration (Feng et al., 2003). It was reported that Exogenous application of spermidine as an important

A

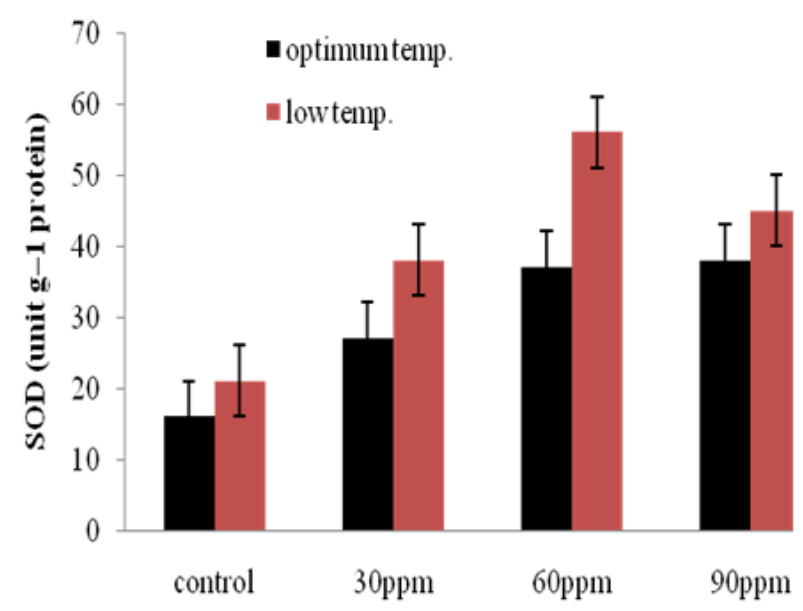

Pre-sowing spermine seed treatments

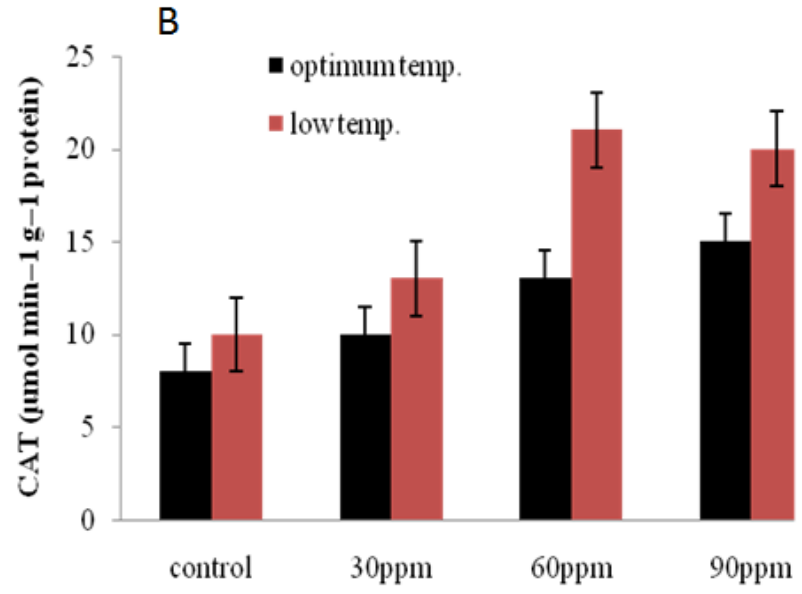

Pre-sowing spermine seed treatments

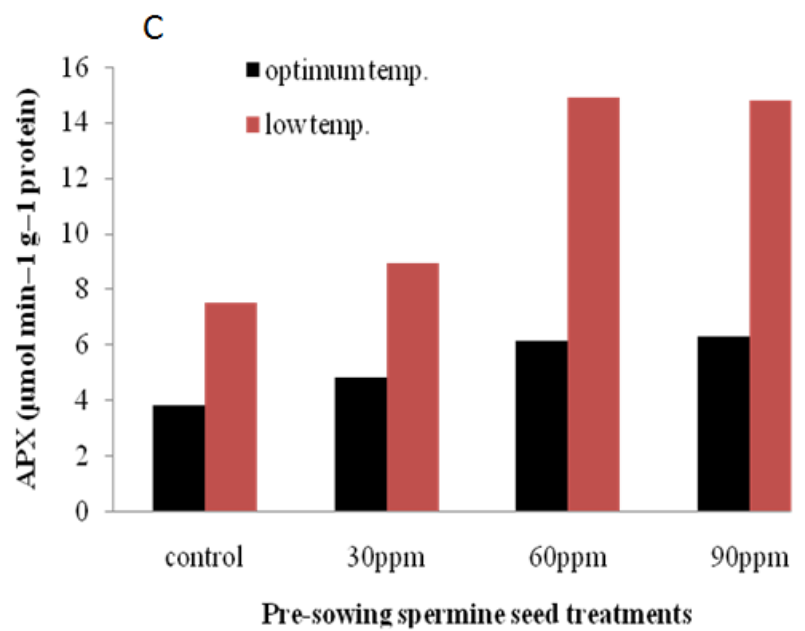

Fig. 4. Response of Antioxidative system of maize seedlings under optimum and low temperature conditions to spermine application including Superoxide dismutase (SOD) (A), Catalaze (B) and Ascorbate Peroxidase (C). Data are the mean value of three replications \pm SE which represented by the vertical bar in each graph 
polyamine plays vital roles in preventing the electrolyte leakage and recovering the plasma membrane damage in rice cultivars in response to salinity, in chilling tolerance and in protection of water stressed cucumber leaves (Kubis, 2008; Roy et al., 2005). Apparently, the effect of spermine on improving the damage of electrolyte leakage caused by chilling stress is achieve to a great extent on high concentrations of spermine. However, the $30 \mathrm{ppm}$ level could significantly reduce the electrolyte leakage of the seedlings under stress and normal conditions.

\section{Antioxidant system activity}

Antioxidant system was efficiently responded to the stress conditions and the priming treatment. The activity of superoxide dismutase (SOD) as an important enzymatic antioxidant was highly increased caused by spermine priming treatment on seedlings under both optimal and low temperature (Fig 4A). The highest value of SOD activity was obtained on seedlings primed with $60 \mathrm{ppm}$ spermine and under low temperature conditions. Although the increasing trend of SOD activity was continued with increased level of spermine on non stressful seedlings, a little decrease was observed on $90 \mathrm{ppm}$ level and under chilling conditions seedlings.

Catalase (CAT) activity was also affected by applied spermine levels (Fig 4B). Catalase activity was increased due to Chilling treatments compared with control plants and it was significantly amplified as the spermine concentration increased. There were no differences between 60 and $90 \mathrm{ppm}$ spermine level regards to catalyze activity.

Priming had a great effect on Ascorbate peroxidase (APX) activity on both stressful and normal seedlings (Fig 4C). Specially, $60 \mathrm{ppm}$ spermine level treatment increased APX activity to a great extent comparing with the previous level. But similarly like CAT, 90 ppm level had no advantage about the enzymes activity related to the $60 \mathrm{ppm}$ level treatment, which may suggest the optimum level of spermine application with respect to the results of the other parameter.

PAs are also widely known to play a vital role on activating the defense mechanisms of plants to various environmental stresses (Cuevas et al., 2008; Groppa and Benavides, 2008; Katsukabe et al., 2004; Xhang et al., 2009), especially oxidative stress (Durmus and Kadioglu, 2005; Rider $e$ t al., 2007).

The activation of several enzymatic (superoxide dismutase, GPX, APX, glutathione reductase and nonenzymatic antioxidants can detoxify produced reactive oxygen species in stressed cells (Blokhina et al., 2003). It is well documented that polyamines counteract oxidative damage in plants by acting as direct free radical scavengers or binding to antioxidant enzyme molecules to scavenge free radical (Bors et al., 1989). Higher endogenous levels of polyamines, particularly spermine and Spermidine are positively correlated with greater increase in antioxidant enzymes in response to environmental stresses. It was sug- gested earlier that the PAs may act indirectly by elevating the levels of antioxidants or gene expression of antioxidant enzymes (Shen et al., 2000; Tang and Newton, 2005; Verma and Mishra, 2005; Wi et al., 2006) resulting in tolerance to numerous abiotic stresses. Result of the enzymatic antioxidants assessment in this experiment is similar to the mentioned achievements.

\section{Conclusions}

Based on the results of this experiment, this can be concluded that spermine has a protective effect on plant tissues exposed to cold stress and this role is mainly related to membrane stabilizing and activating antioxidants production processes in cellular structures.

\section{References}

Apel K, Hirt H (2004). Reactive oxygen species: metabolism oxidative and signal transduction. Ann Rev Plant Mol Biol 55:373-399.

Aroca R, Irigoyen JJ, Sanchez-Diaz M (2003). Drought enhances maize chilling tolerance. II. Photosynthetic traits and protective mechanisms against oxidative stress. Physiol Plant 117:540-549.

Association of Official Seed Analysis (1990). Rules for testing seeds. J Seed Technol 12:1-112.

Basra SMA, Farooq M, Tabassum R (2005). Physiological and biochemical aspects of seed vigor enhancement treatments in fine rice (Oryza sativa L.). Seed Sci Technol 33:623-628.

Bewley JD, Black M (1985). Seeds physiology of development and germination. Plenum Press New York, $427 \mathrm{p}$.

Blokhina O, Virolainen E, Fagerstedt KV (2003). Antioxidants, oxidative damage and oxygen deprivation stress. A Review. Ann Bot 91:179-194.

Blum A, Ebercon A (1981). Cell membrane stability as a measure of drought and heat tolerance in wheat. Crop Sci 21:4347.

Bors W, Langebartels C, Michel C, Sandermann H (1989). Polyamines as radical scavengers and protectants against ozone damage. Phytochem 28:1589-1595.

Campos PS, Quartin V, Ramalho JC, Nunes, MA (2003). Electrolyte leakage and lipid degradation account for cold sensitivity in leaves of Coffea sp. Plants J Plant Physiol 160:283292.

Coolbear P, Francis A, Grierson D (1984). The effect of low temperature pre-owing treatment under the germination performance and membrane integrity of artificially aged tomato seeds. J Exp Bot 35:1609-1617.

Cuevas JC, Lopez-Cobollo R, Alcazar R, Zarza X, Koncz C, Altabella T, Salinas J, Tiburcio AF, Ferrando A (2008). Putrescine is involved in Arabidopsis freezing tolerance and cold acclimation by regulating $\mathrm{ABA}$ levels in response to low temperature. Plant Physiol 148:1094-1105. 
116

Dubey RS (1997). Photosynthesis in plants under stressful conditions, 975 p. In: Pessarakli M (Ed.). Handbook of Photosynthesis. Marcel Dekker Inc, New York.

Durmus N, Kadioglu A (2005). Spermine and putrescine enhance oxidative stress tolerance in maize leaves. Acta Physiol Plant 27:515-522.

Ellis RA, Roberts EH (1981). The quantification of ageing and survival in orthodox seeds. Seed Sci Technol 9:373-409.

Farooq M, Basra SMA, Hafeez K, Ahmad N (2005). Thermal hardening: a new seed vigor enhancement tool in rice. J Integr Plant Biol 47:187-193.

Farooq M, Basra SMA, Hafeez K (2006 a). Rice seed invigoration by osmo-hardening. Seed Sci Technol 34:181-187.

Farooq M, Basra SMA, Khalid M, Tabassum R, Mehmood T (2006 b). Nutrient homeostasis, reserves metabolism and seedling vigor as affected by seed priming in coarse rice. Can J Bot 84:1196-1202.

Farooq M, Basra SMA, Tabassum R, Afzal I (2006 c). Enhancing the performance of direct seeded fine rice by seed priming. Plant Prod Sci 9:446-456.

Farooq M, Basra SMA, Rehman H, Saleem BA (2008 a). Seed priming enhances the performance of late sown wheat (Triticum aestivum L.) by improving chilling tolerance. J Agron Crop Sci 194:55-60.

Farooq M, Aziz T, Hussain M, Rehman H, Jabran K, Khan MB (2008 b). Glycinebetaine improves chilling tolerance in hybrid maize. J Agron Crop Sci 194:152-160.

Feng Z, Guo A, Feng Z (2003). Amelioration of chilling stress by triadimefon in cucumber seedlings. Plant Growth Regul 39:277-283.

Foyer CH, Vanacker H, Gornez LD, Harbinson J (2002). Regulation of photosynthesis and antioxidant metabolism in maize leaves at optimal and chilling temperatures: review. Plant Physiol Biochem 40:659-668.

Kubis J (2001). Polyamines and "scavenging system": influence of exogenous spermidine on Halliwell-Asada pathway enzyme activity in barley leaves under water deficit. Acta Physiol Plant 23:335-341.

Groppa MD, Benavides MP, Tomaro ML (2003). Polyamine metabolism in sunflower and wheat leaf discs under cadmium or copper stress. Plant Sci 161:481-488.

Groppa MD, Benavides MP (2008). Polyamines and abiotic stress: recent advance. Amino Acids 34:35-45.

Ha HC, Sirisoma NS, Kuppusamy P, Zweier JL, Woster PM, Casero RA (1998). The natural polamine spermie functions directly as a free radical scavenger. Biochem 95:1140-1145

Haldimann A, Fisher SL, Daniels LL, Walsh CT, Wanner BL (1997). Transcriptional regulation of the Enterococcus faecium BM4147 vancomycin resistance gene cluster by the VanS-VanR two-component regulatory system in Escherichia coli K-12. J Bacteriol 179(18):5903-5913.

Hayat S, Ahmad A (2007). Salicylic Acid-A Plant Hormone. Springer Dordrecht the Netherlands, 1-14 p.
Kasinathan V, Wingler A (2004). Effect of reduced arginine decarboxylase activity on salt tolerance and on polyamine formation during salt stress in Arabidopsis thaliana. Physiol Plant 121:101-107.

Katsukabe Y, He L, Nada K, Misawa S, Ihara I, Tachibana S (2004). Overexpression of spermidine synthase enhances tolerance to multiple environmental stresses and up-regulates the expression of various stress-regulated genes in transgenic Arabidopsis thaliana. Plant Cell Physiol 45:712-722.

Kubi's J (2008). Exogenous spermidine differentially alters activities of some scavenging system enzymes, $\mathrm{H}_{2} \mathrm{O}_{2}$ and superoxide radical levels in water-stressed cucumber leaves. J Plant Physiol 165:397-406.

Lee SS, Kim JH (2000). Total sugars, a-amylase activity, and emergence after priming of normal and aged rice seeds. Kor J Crop Sci 45:108-111.

Lee SH, Singh AP, Chung GC, Kim YS, Kong IB (2002). Chilling root temperature causes rapid ultrastructural changes in cortical cells of cucumber (Cucumis sativus L.) root tips. J Exp Bot 53:2225-2237.

Leipner J, Fracheboud Y, Stamp P (1999). Effects of growing season on the photosynthetic apparatus and leaf antioxidative defenses in two maize genotypes of different chilling tolerance. Environ Exp Bot 42:129-139

Leshem Y (1992). Plant membranes: A biophysical approach to structure, development and senescence. Kluwer Academic Publishers Dordrecht, 280 p.

Luck H (1974). Catalases, 885-888 p. In: Bergmeyer HU (Ed.). Methods of Enzymatic Analysis, Volume 2, Academic Press, New York.

Martin-Tanguy J (2001). Metabolism and function of polyamines in plants: recent development (new approaches). Plant Growth Regul 34:135-148.

McCord JM, Fridovitch I (1969). Superoxide dismutase: an enzymic function for erythrocuprein (hemocuprein). J Biol Chem 244:6049-6055.

McDonald MB (1999). Seed deterioration: physiology, repair and assessment. Seed Sci Technol 27(1):177-237.

Muthuchelian K, Bertamini M, Nedunchezhian N (2001). Triacontanol can protect Erythrina variegate from cadmium toxicity. J Plant Physiol 158:1487-1490.

Nakano Y, Asada K (1987). Purification of ascorbate peroxidase in spinach chloroplasts: its inactivation in ascorbate depleted medium and reactivation by monodehydroascorbate radical. Plant Cell Physiol 28:131-140.

Nayyar H, Chander S (2004). Protective effects of polyamines against oxidative stress induced by water and cold stress in chickpea. J Agron Crop Sci 190:355-365.

Parera CA, Cantliffe DJ (1994). Presowing seed priming. Hortic Rev16(16):109-141.

Paschalidis KA, Roubelakis-Angelakis KA (2005). Spatial and temporal distribution of polyamine levels and polyamine anabolism in different organs/tissues of the tobacco plant. 
Correlations with age, cell division/expansion, and differentiation. Plant Physiol 138:142-152.

Pinhero RG, Rao MV, Paliyath G, Murr DP, Fletcher RA (1997). Changes in activities of antioxidant enzymes and their relationship to genetic and paclobutrazol-induced chilling tolerance of maize seedlings. Plant Physiol 114:695-704.

Rider JE, Hacker A, Mackintosh CA, Pegg AE, Woster, PM, Casero Jr RA (2007). Spermine and spermidinemediate protection against oxidative damage caused by hydrogen peroxide. Amino Acids 33:231-240.

Roy P, Niyogi K, SenGupta DN, Ghosh B (2005). Spermidine treatment to rice seedlings recovers salinity stress induced damage of plasma membrane and PMbound H+-ATPase in salt-tolerant and salt-sensitive rice cultivars. Plant Sci 168:583-591.

Sairam RK, Srivastava GC, Agarwal S, Meena RC (2005). Differences in antioxidant activity in response to salinity stress in tolerant and susceptible wheat genotypes. Biol Plant 49:85-91.

Sanchez DH, Cuevas JC, Chiesa MA, Ruiz OA (2005). Free spermidine and spermine content in Lotus glaber under long-term salt stress. Plant Sci 168:541-6.

Schutzendubel A, Polle A (2002). Plant responses to abiotic stresses: heavy metal induced oxidative stress and protection by mycorrhization. J Exp Bot 53:1351-1365.

Shen WY, Nada K, Tachibana S (2000). Involvement of polyamines in the chilling tolerance of cucumber cultivars. Plant Physiol 124:431-439.

Skrudlik G, Baczek-Kwinta R, Koscielniak J (2000). The effect of short warm breaks during chilling on photosynthesis and the activity of antioxidant enzymes in plants sensitive to chilling. J Agron Crop Sci 184:233-240.
Sowinski P, Rudzinska-Langwald A, Adamczyk J, Kubica I, Fronk J (2005). Recovery of maize seedlings growth, development and photosynthetic efficiency after initial growth at low temperature. J Plant Physiol 162:67-80.

Tang W, Newton RJ (2005). Polyamines reduce salt-induced oxidative damage by increasing the activities of antioxidant enzymes and decreasing lipid peroxidation in Virginia pine. Plant Growth Regul 46:31-43.

Verma S, Mishra SN (2005). Putrescine alleviation of growth in salt stressed Brassica juncea by inducing antioxidative defense system. J Plant Physiol 162:669-677.

Verheul MJ, Picatto C, Stamp P (1996). Growth and development of maize (Zea mays L.) seedlings under chilling conditions in the field. Eu J Agron 5:31-43.

Wi SJ, Kim WT, Park KY (2006). Overexpression of carnation $S$-adenosylmethionine decarboxylase gene generates a broad-spectrum tolerance to abiotic stresses in transgenic tobacco plants. Plant Cell Rep 25:11-21.

Xiong L, Schumaker KS, Zhu JK (2002). Cell signaling during cold, drought, and salt stress. Plant Cell 14:165-183.

Xu S, Hu J, Li Y, Ma W, Zheng Y, Zhu S (2010). Chilling tolerance in Nicotiana tabacum induced by seed priming with putrescine. J Plant Growth Regul 63(3):279-290.

Yamaguchi K, Takahashi Y, Berberich T, Imai A, Miyazaki A, Takahashi T (2006) The polyamine spermine protects against high salt stress in Arabidopsis thaliana. FEBS Lett 580(30):6783-6788.

Zhang W, Jiang B, Li W, Song H, Yu Y, Chen J (2009). Polyamines enhance chilling tolerance of cucumber ( $\mathrm{Cu}$ cumis sativus $\mathrm{L}$.) through modulating antioxidative system. Sci Hortic 122:200-208. 